folk/ed. Derg, 2021; 27(4)-108. sayı

DOI: $10.22559 /$ folklor.1846

\title{
The Kinship Commodification of Local Ethnic in Lampung in Multicultural Relations
}

\author{
Lampung'daki Yerel Etnik Yapının \\ Çokkültürlü İlişkilerle Metalaşması
}

\section{Risma Margaretha Sinaga*}

\begin{abstract}
One of the common problems in a society that originates from multiculturalism is the emergence of a dichotomy in the community resulting in differences between ethnic groups. This distinction is often measured by domination, marginalization, majority or minority, and even stereotypes attached to each group or ethnicity. Not infrequently also formed a pattern that labels a local community and migrants. The complexity of inter-ethnic relations in multicultural societies requires controlling models for the relations with conflict potential. Actually, the concept of ethnic identity still leaves debate that is not over, especially among experts in the social sciences. However, at least we need to get an overview of this construct. One of the strongest elements in the cultural structure of a society that can support
\end{abstract}

Geliş tarihi (Received): 30-04-2021 - Kabul tarihi (Accepted): 15-10-2021

* Dr., University of Lampung History Education Department. risma.margaretha@fkip.unila.ac.id. ORCID 0000$0002-3212-2614$ 
multicultural relationships that are equilibrium and harmony is kinship because there is a mechanism in maintaining wholeness. This study aims to reveal the meaning of kinship commodification in local ethnic groups in Lampung and reveal the implicit meaning of the commodification of kinship. As a qualitative study, interviews were the main instrument for obtaining a native perspective (the giver and recipient of a title) and observing the custom ritual of awarding the title holistically and supported by several relevant documents. Collected data by rolling out information on some (original) informants to get their perspective on the culture of lifting titles for migrants who used a kinship perspective. This study also used participatory observation to get a complete picture of the commodification of kinship in multicultural relationships. The research location included the Lampung society dominated by Papadun and Saibatin communities. The results showed that the positioning of Lampung ethnicity at the minority level in a multicultural society increased their ability to cultivate a title culture in their community structure as a tool of resistance by adopting kinship. Cultural actions with kinship patterns and symbols make other people like relatives or family. Even the title becomes an instrument of cultural harmony in multicultural relations. The title of Lampung's local ethnic kinship becomes the identity at stake because the title found a compromise of identity that is always modified.

Keywords: custom title, identity, kinship, commodification, multicultural, Lampung

\section{Öz}

Bir toplumda çok kültürlülükten kaynaklanan yaygın sorunlardan biri, toplulukta etnik gruplar arasında farklılıklara neden olan bir ikiliğin ortaya çıkmasıdır. Bu ayrım genellikle tahakküm, marjinalleşme, çoğunluk veya azınlık ve hatta her bir gruba veya etnik kökene bağlı klişelerle ölçülür. Nadiren de olsa yerel bir topluluğu ve göçmenleri etiketleyen bir kalıp oluşturdu. Çok kültürlü toplumlarda etnik gruplar arası ilişkilerin karmaşıklığı, çatışma potansiyeli olan ilişkiler için kontrol modelleri gerektirir. Aslında etnik kimlik kavramı, özellikle sosyal bilimler uzmanları arasında hala bitmemiş bir tartışma bırakmaktadır. Ancak, en azından bu yapıya genel bir bakış elde etmemiz gerekiyor. Bir toplumun kültürel yapısında denge ve uyum olan çok kültürlü ilişkileri destekleyebilecek en güçlü unsurlardan biri akrabalıktır, çünkü bütünlüğün sağlanmasında bir mekanizma vardır. Bu çalışma, Lampung'daki yerel etnik gruplarda akrabalığın metalaştırılmasının anlamını ortaya koymayı ve akrabalığın metalaştırılmasının örtük anlamını ortaya koymayı amaçlamaktadır. Nitel bir çalışma olarak, mülakatlar yerel bir bakış açısı (bir unvanın sahibi ve alıcısı) elde etmenin ve unvanın bütünsel olarak verilmesine ilişkin geleneksel ritüeli gözlemlemenin ve ilgili birkaç belgeyle desteklenen ana araçtı. Akrabalık perspektifi kullanan göçmenler için unvanları kaldırma kültürüne ilişkin bakış açılarını elde etmek için bazı (orijinal) muhbirler hakkında bilgi dağıtarak toplanan veriler. Bu çalışma aynı zamanda çok kültürlü ilişkilerde akrabalığın metalaşmasının tam bir resmini elde etmek için katılımcı gözlemi kullandı. Araştırma yeri, Papadun ve Saibatin topluluklarının egemen olduğu Lampung toplumunu içeriyordu. Sonuçlar, Lampung etnik 
kökeninin çok kültürlü bir toplumda azınlık düzeyinde konumlandırılmasının, akrabalığı benimseyerek bir direniş aracı olarak topluluk yapılarında bir unvan kültürü geliştirme yeteneklerini artırdığını gösterdi. Akrabalık kalıpları ve sembolleri olan kültürel eylemler, diğer insanları akraba veya aile gibi yapar. Başlık bile çok kültürlü ilişkilerde kültürel uyumun bir aracı haline gelir. Lampung'un yerel etnik akrabalığı unvanı, söz konusu kimlik haline gelir, çünkü unvan her zaman değiştirilen bir kimlik uzlaşması buldu.

Anahtar sözcükler: özel başlık, kimlik, akrabalık, metalaşma, çok kültürlü, Lampung

\section{Introduction}

One of the common problems in a society that originates from multiculturalism is the emergence of a dichotomy in the community resulting in differences between ethnic groups. This distinction is often measured by domination, marginalization, majority or minority, and even stereotypes attached to each group or ethnicity. Not infrequently also formed a pattern that labels a local community and migrants. As a result, various problems vary because the understanding of multiculturalism depends on the underlying conditions such as politics, religion, race, ethnicity, and other things. Various conditions due to the inability to overcome problems originating from multiculturalism can increase the complexity of the relationship between local and migrants, which triggers disharmony due to the imbalance of interactions between them (Hoon, 2013).

In many cases, the potential for conflict in multicultural societies is because each ethnic / group requires identity identification. From a multicultural perspective, group representation can also be seen from the collective bonds of society in the form of morals, law, religion, politics and other regulations (Rapport, 2014). Thus, identity is needed to differentiate (oneself) from (others), although adaptation is still necessary. Meanwhile, on the one hand, diversity is a set of conscious practices that involve an understanding of the interdependence between humans, culture and nature; practice respecting differences in experiences, defending rights, and building differences across alliances to eradicate all forms of discrimination (Patrick \& Kumar, 2012). It takes commitment and obedience to harmony in other communities, such as sanctions, to keep the community in control. Therefore, diversity includes acceptance and appreciation, meaning that it is necessary to understand that each individual is unique and must recognize differences. Many studies on multicultural societies in various countries have been well explored, but studies on the granting of adat titles in Lampung are rarely explored.

\section{Literature review}

Identity ethnic and multicultural: Actually, the concept of ethnic identity still leaves debate that is not over, especially among experts in the social sciences. However, at least we need to get an overview of this construct. Some argue that the notion of ethnic identity shows someone who identifies himself in a certain ethnic group a sense of belonging to that ethnic group and is part of his thoughts, perceptions, feelings and behaviour because he is a member 
of that ethnic group. Ethnic identity is separate from a personal identity as individuals, even though the two influence each other. There are four main components of ethnic identity:

- Ethnic awareness, a person realizes that he has his own ethnicity that is different from other groups;

- $\quad$ ethnic self-identification, the label assigned to the group itself;

- $\quad$ ethnic attitudes, feelings about themselves and other groups;

- Ethnic behaviour typically exists in a certain ethnic group.

According to (Kiang \& Fuligni, 2009), what is peculiar to ethnic identity is an affiliative idea (affiliative construct). Individuals are viewed by themselves and others belonging to a particular ethnic or cultural group. An individual may choose to associate himself or herself with a group, especially if there are other options (e.g. a mixed ethnicity of mixed racial descent). Affiliation can be influenced by race, birth, and symbol (Kiang \& Fuligni, 2009).

The strengthening of identity in multicultural relationships enables each group or ethnicity, reproduce or modify their identity, even choosing another identity to determine their classification category (Barth, 1969; Eriksen \& Jakoubek, 2018). The formation of an identity other than its membership is also obtained from experience interpreted (Haddock \& Sutch, 2004). Today, identity formation is part of trends, various strategies, techniques, or manipulations carried out on material symbols to form new affiliations. What ethnic groups do as a strategy by reconstructing their cultural material patterns is resistance to the groups that dominate them (Hobsbawm, 2012).

Being aware of the crucial potential arising from multicultural relationships, a review of the structure of society and patterns of interaction are important. This awareness cannot be separated from the adoption of knowledge gained from relationships with others (Rutherford, 2000). Moreover, social problems arising from multicultural relations are complex, such as ethnicity, nationalism, race, religion, and other matters relating to integration, nationality, and primordial sentiments (Liang, 2014).

Kinship pattern: One of the strongest elements in the cultural structure of a society that can support multicultural relationships that are equilibrium and harmony is kinship because there is a mechanism in maintaining wholeness. The kinship pattern prevailing in the community group has the opportunity to create identity. At this level, the role of the family becomes crucial in the formation of identity and even becomes a source of imbalance among its members. The mechanism of kinship is in the form of group division or positioning, which functions as a social force and maintains rules because, in fact, kinship exists and is defined as a relationship that arises from the process of human sexual reproduction. Human sexuality is essentially a biological process, a natural part of humans, and is valued as cultural aspects. Kinship will not be meaningful without a cultural construction because kinship is the root, which underlies basic human needs, tendencies, encouragement, which is the natural side of humans. Kinship is interpreted as personal ties based on the results of social interpretation, as a complex system and unilateral reinterpretation (Schneider, 2014). 
Kinship plays an important role as a social force. It is the basis for maintaining rules so that kinship creates social solidarity relationships and raises rules about kinship, marriage, territory, or residence of people according to their social role and identity. (Schneider, 2014) argues that the division of groups and one's position has been arranged in a kinship called basic group kinship, and there is a group called derivative kinship (modified kinship). The "brother" kinship metaphor is the glue element in the dynamics of multicultural relations. The word "brother" is often used to describe the level of closeness of a relationship, so the mention of siblings, distant relatives or close relatives becomes a measure of kinship. Reconstruction of identity through the term "brother" becomes prestige, especially if those who claim you have a higher social status. At this level, the term "brother" becomes a new value in identity construction because of the recognition. As a result, the construction of "brother" becomes a necessity even legalized by various cultural rituals for the sake of existence. In fact, being a "brother" is usually due to (a) marriage and (b) genealogical (family/blood) relationships. Even sibling ties built based on marital or genealogical factors also have consequences such as one's position or level in a circle of kinship in social relations.

Sociocultural structure of the Lampung: In the sociocultural structure of the Lampung community, the kinship mechanism functions to maintain the integrity of people's lives consisting of the values, norms, identity, and self-esteem components of each community group. The "title" ritual carried out by the Lampung ethnic group is one component of identity that shows kinship relations and normatively only applies to groups that are truly relatives. It takes a variety of efforts, including material sacrifice, to get recognition among the internal community of Lampung itself. It takes a variety of efforts, including material sacrifice, to get recognition among the internal community of Lampung itself.

At present, the title is easily given to migrants as a "brother" bond, as the study about an honour conducted by (Bourdieu, 1979; Corr, 2003). Traditionally the title is only imposed and given to certain circles in ethnic Lampung internally. They use the familial way of working that is commodified, with the culture of giving customary title to migrant ethnic groups as adoption media called "brother". Referring to the (Castells, 2011), Lampung's ethnic action implies that the title is the most rational construction of identity material because the title is not just an identity or attribute attached but as a reality of change, experiencing commodification which is used as a strategy to reshape its identity (John \& Comaroff, 2010; Schneider, 2014).

Fictitious relatives or pseudo relatives, or relatives who are manipulated and defined as family relationships even though not based on blood or marriage relationships, this model tends to religious and friendship rituals (Ebaugh \& Curry, 2000). It even became one of the capitals used by the two groups (local migrants) to incorporate into the local community. Fictitious kinship in migrant populations everywhere has the same function of expanding social networks, including problem-solving solutions.

The ability of ethnic Lampung to redefine kinship through the customary title ritual in the internal scope is indeed related to the concept of a dynamic culture, and the formation of identity is always ongoing and never steady (Goodenough, 2003; King, 1991; Ortner, 
2006). The ethnic capacity of Lampung utilizing opportunities with kinship engineering to determine its position in multicultural relations is one of the interesting points in this paper. The analogy of kinship with the customary title ritual to others shows that cultural material can be manipulated according to group needs at some level as the purpose of this paper (Thomas Hylland \& Finn, 2013; Woodward, 1999). Based on the description above, by observing the position of Lampung ethnicity in multicultural societies, this research was focused on the commodification of kinship "CUSTOMARY TITLE", and the research questions were (1) discussing the commodification of kinship strategies and mechanisms legalized by local ethnic culture in Lampung; (2) reveal the implicit meaning of the commodification of kinship.

\section{Methods}

The nature of this research was qualitative, by setting the Lampung community (papadun and saibatin) as subjects so that the perspectives of the two local ethnic groups were obtained from the commodification of kinship. All subjects (informants) had the same opportunity wherever they were. Data was collected by rolling out information on a number of (original) informants to get their perspective on the culture of lifting titles for migrants who used a kinship perspective (Borofsky, 1994). This study also used participatory observation to get a complete picture of the commodification of kinship in multicultural relationships. The research location included the Lampung society dominated by Papadun and Saibatin communities.

\section{Results}

Title/Degree: Identity in the structure of kinship: In the kinship structure of the Lampung community, the terms of designation and vocation were important elements, because in their life cycle the name change would be made by all people especially those who were Papadun. Changes in vocations from first names (juluk-adok) according to the level and position in the family based on the position of birth would experience a change in vocations. Change the name as customary law was to give and receive the title, it usually did at the time of marriage, as the concept of (Ember \& Ember, 2007), that many communities give power and roles to boys, especially the successors of the clan, and also a successor to the economic survival of the extended family.

There were several vocations in the kinship of Lampung ethnic according to their titles and status (dalom, kanjeng, stan, minak, ratu), which functioned as identifiers between individuals that caused titles to be important. Transitioning a small name to become a title should not be given carelessly, even though the process of traditional ceremonies that were expensive and witnessed by traditional leaders. Not surprisingly, the customary title was still the dream of most ethnic Lampung. The title as a symbol of identity resulted in them competing to get it despite the risk. Even the extreme ways were also done such as selling property, borrowing money, or other ways to win a title/degree. 
The complexity and implications of the title gained to the extreme caused the potential for increasing family disputes, structural poverty, and even psychiatric disorders. According to (Groen et al., 2018), there is a relationship between cultural identity and mental health, including the relationship of stress with changes in cultural identity. The title/degree became an inherent identity, but the procedure for obtaining it differed between the two local subethnic variants of Lampung, namely Saibatin and Papadun.

According to the Saibatin tradition, the titles were arranged according to kinship, genealogy, are internal, decisive, could not be transferred or given to others outside the direct kinship line. On the other hand, in Papadun society, a title besides being inherited genealogically, it could also be purchased as long as it was economically capable. Those who bought title were usually not the oldest boys. This condition refers to (Sutterlüty, 2006) thought, that power over blood relations as biological inheritance is still maintained and highly trusted by a group of people as practiced by the Saibatin indigenous people, so it is very clear that kinship does have to take into account many things including differences due to consanguinis or afinal (Bonvillain, 2017).

The commodification of kinship: A formulation in multicultural relations: Awarding the title was a local identity that was displayed to the public to get recognition. The commodification of kinship by being "brothers" was a formulation in multicultural relations. Based on cultural diversity, actually each ethnic group has its own kinship formulation (Edwards, 2013). Interestingly, the title which was a form of ethnic Lampung's identity was also in demand by immigrants. The interest of migrants in the "titles" became a moment for ethnic Lampung to emerge from immigrant domination, and to take a subtle position. A title was commodified because there was a bargain, and there was a price to pay for a title. The title became a cultural commodity for those who were interested, the formulation of the title changed from sacred to profane because it was more easily given to migrants who were willing provided the conditions could be met.

In addition to the ceremonial material requirements of awarding such as the amount of economic value paid, there were still other conditions such as requirements for men and women, space limits that could be crossed by participants and ceremonial event invitations, even body positions were arranged in such a way and all of them must be obeyed by those who would be given a title and would be attracted to the ritual. Violation of the requirements at the awards ceremony in addition to being reprimanded in front of the general public was also subject to custom fines in the form of money.

Lampung's local ethnic ability to manage kinship by providing space for outsiders (migrants) to enter with the label "brothers" indicated open contestation in symbolic form, the fulfillment of the needs of existence, recognition, representation of ethnic identity among the multicultural cultural heterogeneity of the multicultural society, and competition between groups marginal with cultural, political and economic dominance. From the ethnic side of immigrants, the new title was the process of migrants becoming local and the implication of 
this title was that it was no longer only owned by local ethnic groups whose status was equal (the first male in the family), but the commodification of kinship.

The implementation of a customary title for migrants by turning others into relatives/ brothers/guests was seen as a symbol of openness in the ethnic Lampung as a historical journey. Receiving/giving a title with the requirements in multicultural relations was seen as (a) for the ethnic Lampung recognition and appreciation of local culture, (b) for newcomers to the form of thanks for having been given space/place to settle/live together.

The meaning of commodification of kinship in multicultural relations: Constructing identity using mechanisms and ways of working for kinship was the most basic strategy in multicultural relations. The term "brother" had a magical element in bringing a relationship closer. The title recipient was culturally bound to the title giver, became part of their culture and accepted the consequences of the title given along with the rights and obligations as a member of a relative. Recognizing others as "brothers" legalized through the award ceremony of giving the title, could be classified as kinship type fictive kinship, it was a kinship that was not based on blood or marriage but was bound by ethics of mutual respect and courtesy, even though it was not a true form of kinship.

Embracing others through the symbol of the title into the environment of Lampung's local ethnic traditions was also resistance and reaction in order to create parallels between the recipient group and the minority group (title suppliers). Carrying out the rapture of the appointment of "brothers" was contestation and negotiation using local ethnic cultural capital which in the perspective of symbolic power, the position of the giver is higher than the recipient (Jenkins, 2010). Distributing internal titles through kinship was beneficial for both parties, namely the need to be accepted by local ethnic groups and valued by ethnic migrants for the creation of our-you/self-others/self-other relationships that were in accordance with the principle of cultural reciprocity.

The kinship was the strongest line for achieving integration and harmonization in multicultural relationships. Formally, the kinship was often defined by blood relations, so that blood became a symbol of interrelated family relationships. In the tradition of giving titles that were bound through the idea of kinship, this illustrated family affiliation between Lampung's local ethnic groups and migrant ethnic groups, as well as forms of local ethnic responses to the dynamics of change.

\section{Discussion and analysis}

The commodification of kinship in the granting of customary titles meant equality and balance between local ethnic groups and other groups. Giving the customary title through the kinship mechanism was the exchange and competition for cultural capital. Identity was related to positioning themselves among various groups so that in the formation of identity the ability to take advantage of opportunities was also crucial. This was what was done by ethnic Lampung when carrying out the commodification of kinship by holding ceremonies to 
give customary title as commodities.

The kinship played an important role in the structure of Lampung society, because family relationships were formed based on marriage and blood relations, and even the reason men became family heads. Men are considered important so marriage and kinship are an honor that must be at stake (Schultheis et al., 2009). The kinship was the collective property of the local community and the identity of the community was used as the basis for relations in the social system. The kinship is inherited from generation to the next generation through cultural values contained in it (Sungkharat et al., 2010). Once the importance of kinship, especially in maintaining the sustainability of the social structure of society because it could decide who was a relative, which was taboo, and also determined the obligations of members in all religious practices from birth to death in family life.

Pursuing identity with various cultural rituals in Lampung's local ethnic tradition was considered as historical awareness to fight in symbolic form with the aim of meeting the needs of existence. Behind the splendor of cultural symbols built by local Lampung ethnicities for a traditional ritual "making a brother and family" was a reflection of the identity of equality in the multicultural world. The commodification of kinship "being a family member" was resistance that ran naturally so that conflict could be avoided. On the other hand, (migrants) through the "family" metaphor was also a process of exchanging needs between local ethnic groups as producers who gavethe titles to migrants as consumers.

Through exchanges, local ethnic groups regain their identity because in the process of granting titles to ethnic migrants the dignity of being "Lampung people" increases with the inclusion of migrants into local ethnic cultural symbols called cultural incorporation (Sinaga, 2014). When the kinship was engineered for the public, the Lampung ethnic group got a representation of its identity by strengthening its ethnic collectivity so as to create a cultural identity and identity strength.

\section{Conclusion}

Kinship with all its elements cannot be separated from social structure, undergoes a long process until finally found space to reconstruct contextually according to the perspective of local ethnicity. The title in the kinship structure is not only owned by local Lampung ethnic groups, but it is owned by the public because it is implemented into a broader domain as a means of competition. Although the title begins with social inequality and unbalanced position in the local culture, but for the sake of self-esteem becomes a trigger to rise from the domination of immigrants, even the title becomes an instrument of cultural harmony in multicultural relations. In the context of multiculturalism, the title of Lampung's local ethnic kinship becomes the identity at stake, because in the title found a compromise of identity that is always modified. 


\section{Notes}

The title made someone had the right to speak in custom at any traditional ceremony on a local scale, national or even international, the right to provide support, had the right to sit in a customary court (in the Papadun chair), without a title someone was only a spectator. The kinship was the strongest line for achieving integration and harmonization in multicultural relationships.

\section{References}

Barth, F. (1969). Ethnic groups and boundaries: The Social Organization of Cultural Difference Little Brown. In: Boston.

Bonvillain, N. (2017). Cultural anthropology. Pearson.

Borofsky, R. (1994). On the knowledge and knowing of cultural activities. Assessing cultural anthropology, 331-347.

Bourdieu, P. (1979). Algeria 1960: The disenchantment of the world, the sense of honour, the Kabyle house or the world reversed (Vol. 1). Cambridge [Eng.]; Cambridge University Press.

Castells, M. (2011). The power of identity (Vol. 14). John Wiley \& Sons.

Corr, R. (2003). Ritual, knowledge, and the politics of identity in Andean festivities. Ethnology, 39-54.

Ebaugh, H. R., \& Curry, M. (2000). Fictive kin as social capital in new immigrant communities. Sociological Perspectives, 43(2), 189-209.

Edwards, J. (2013). Donor siblings: Participating in each other's conception. Journal of Ethnographic Theory, 3(2), 285-292.

Ember, C. R., \& Ember, M. (2007). Climate, econiche, and sexuality: Influences on sonority in language. American Anthropologist, 109(1), 180-185.

Eriksen, T. H., \& Jakoubek, M. (2018). Ethnic groups and boundaries today: a legacy of fifty years. Routledge.

Goodenough, W. H. (2003). In pursuit of culture. Annual review of Anthropology, 32(1), 1-12.

Groen, S. P., Richters, A., Laban, C. J., \& Devillé, W. L. (2018). Cultural identity among Afghan and Iraqi traumatized refugees: Towards a conceptual framework for mental health care professionals. Culture, Medicine, 42(1), 69-91.

Haddock, B., \& Sutch, P. (2004). Multiculturalism, identity and rights. Routledge.

Hobsbawm, E. J. (2012). Nations and nationalism since 1780: Programme, myth, reality. Cambridge University press.

Hoon, C.Y. (2013). Multicultural citizenship education in Indonesia: The case of a Chinese Christian school. Journal of Southeast Asian Studies, 490-510.

Jenkins, R. (2010). Membaca Pikiran Pierre Bourdieu, diterjemahkan oleh Nurhadi. Yogyakarta: Kreasi Wacana.

John, L., \& Comaroff, J. (2010). Ethnicity, inc. The Hedgehog Review, 12(1), 89-92.

Kiang, L., \& Fuligni, A. J. (2009). Ethnic identity in context: Variations in ethnic exploration and belonging within parent, same-ethnic peer, and different-ethnic peer relationships. Journal of Youth Adolescence, 38(5), 732-743.

King, A. D. (1991). Culture, globalization and the world system: Contemporary conditions for the representation of identity (Vol. 3). U of Minnesota Press. 
Liang, Y. (2014). The causal mechanism of migration behaviors of African immigrants in Guangzhou: from the perspective of cumulative causation theory. The Journal of Chinese Sociology, 1(1), 1-25.

Ortner, S. B. (2006). Anthropology and social theory: Culture, power, and the acting subject. Duke University Press.

Patrick, H. A., \& Kumar, V. R. (2012). Managing workplace diversity: Issues and challenges. Sage Open, 2(2), 2158244012444615.

Rapport, N. (2014). Social and cultural anthropology: The key concepts. Routledge.

Rutherford, D. (2000). The white edge of the margin: Textuality and authority in Biak, Irian Jaya, Indonesia. American ethnologist, 27(2), 312-339.

Schneider, D. M. (2014). American kinship: A cultural account. University of Chicago Press.

Schultheis, F., Holder, P., \& Wagner, C. (2009). In Algeria: Pierre Bourdieu's photographic fieldwork. The Sociological Review, 57(3), 448-470.

Sinaga, R. M. (2014). Revitalisasi tradisi: Strategi mengubah stigma Kajian piil pesenggiri dalam budaya lampung. Masyarakat Indonesia, 40(1), 109-126.

Sungkharat, U., Doungchan, P., Tongchiou, C., \& Tinpang-nga, B. (2010). Local wisdom: the development of community culture and production processes in Thailand. International Business Economics Research Journal, 9(11).

Sutterlüty, F. (2006). The belief in ethnic kinship: A deep symbolic dimension of social inequality. Ethnography, 7(2), 179-207.

Thomas Hylland, E., \& Finn, S. N. (2013). A History of Anthropology. In: Pluto Press.

Woodward, K. (1999). Identity and difference. Identities, culture and media. In: Sage 